\title{
A BIBLIOGRAPHY ON THE LANGUAGE LABORATORY 1968-1971
}

by Ernest $A$. Frechette

ACKERLEY, A. W. "Three Experiments in Teaching Languages. 2 Informal Language Laboratories." $A E$ (London) 43,5 (January, 1971), 302-06.

ACOUSTRON CORPORATION. "How Small or How Large: The Sensible Use of Touch-Tone Retrieval Systems in Education." NALLDJ 4,1 (October, 1969), 78-82.

ADAMS, E. N. "A Proposed Computer-Controlled Language Laboratory," in Modern Language Teaching: Papers from the 9th F.I.P.L.V. Congress, Hans Jalling, Ed., London: Oxford U.P., 1968, 54-62.

ADAMS, E. N. "A Single Station Language Laboratory with Novel Control Characteristics." NALLDJ 4,2 (December, 1969), 12-22.

AGER, D. E. "Advanced Students in the Language Laboratory." Visual Education (May, 1970), 13-15.

AGER, D. E. " 'Open-Ended' Exercises in the Language Laboratory." ML 50,2 (June, 1969), 73-78.

ALEAMONI, LAWRENCE M. and RICHARD E. SPENCER. "An Evaluation of the Pennsylvania Foreign Language Project." MLJ 53,6 (October, 1969), 421-28.

ALLEN, ROBERT L. "A Reassessment of the Role of the Language Laboratory." JESL 3,1 (1968), 49-58.

ALTAMURA, NICHOLAS C. "The Language Laboratory-A Financial Liability." FR 43,5 (April, 1970), 819-20.

BANATHY, BELA $\mathrm{H}$. and BORIS JORDAN. "A Classroom Laboratory Instructional System (CLIS)." FLA 2,4 (May, 1969), 466-73.

BARRUTIA, RICHARD. "Technology and Teaching - A Work Paper for AATSP." NALLDJ 5,2 (December, 1970), 26-30.

BASSETT, RALPH W. "The High School Language Laboratory as the Supervisor Sees It." NALLDJ 4,1 (October, 1969), 31-31.

BIRKMAIER, EMMA M. and DALE L. LANGE. "What About the Pennsylvania Studies?" Today's Education 58,7 (October, 1969), 49-50.

BRASNETT, CLIVE. "A Survey of Language Laboratory Usage." EngLT 22 (May, 1968), 253-60. 


\section{Bibliography}

BROWN, M. W. F. "The 'Friedlab'." ML 51,3 (September, 1970), 95. BUNG, KLAUS, ed. Programmed Learning and the Language Laboratory 1. London: Longmac, 1968.

BUNG, KLAUS. "Towards Truly Programmed Language Laboratory Courses." AvLJ 7,1 (Spring, 1969), 5-17.

CAMPBELL, RUSSELL N. "The Language Laboratory and Pronunciation Teaching." EngLT 22,2 (January, 1968), 148-55.

CAMPOS, T. "I Can Hear Myself Read: Advantages of a Mobile Language Laboratory." Texas Outlook 53 (January, 1969), 39.

CANNADAY, ROBERT W. JR. "Hawaii's Massive Language Laboratory Effort: Pluses and Minuses." NALLDJ 5,4 (May, 1971), 43-46.

CAPRETZ, PIERRE J. "The Language Laboratory: A Relic of the Past or the Solution to the Future." NALLDJ 4,1 (October, 1969), $32-42$.

CHOMEI, TOSHIKO and BOB HOULIHAN. "An Experimental Study of the Effectiveress of a Newly Devised Short-Delay Playback System in a Language Laboratory." Audio-Visual Language Journal 6, Nos. 2 \& 3 (Winter \& Spring, 1968-69), 59-72.

CHOMEI, TOSHIKO and ROBERT HOULIHAN. "Comparative Effectiveness of Three Langliage Laboratory Methods Using a New Equipment System." AvCR 18,2 (Summer, 1970), 160-68.

CLARK, JOHN L. D. "The Pennsylvania Project and the "Audio-Lingual vs. Traditional' Question.” MLJ 53,6 (October, 1969), 388-96.

CLAUDEL, CALVIN A. "The Language Laboratory." in: Roucek, Joseph S., ed. The Study of Foreign Languages New York: Philosophical Library (1968), 219-36.

COCHRANE, G. R. "The Teaching of Pronunciation and the Language Laboratory." BabJA 6,2 (July, 1970), 16-20.

COGGLE, PAUL H. "On Questions of an Effective Drill System in the Language Laboratory in Technical Language Instruction." (In German) Deutsche als Fremdsprache 7,1-2 (1970), 111-21.

COLE, LEO R. "Get More Out of Language Laboratories." TES 2766 (May 24, 1968), 1764.

COLTHARP, LURLINE H. "Expanding the Use of the Laboratory." TESOLQ 3,3 (September, 1969), 211-14.

COMPANYS, EMMANUEL. "Problemes psychopédagogiques des laboratoires de langues: Premiere partie." Ann Arbor: University of Michigan Center for Research on Language and Language Behavior (1968), 279-400. ED 023064.

CORDTS, J. M. "Why Language Labs Fail and Why They Succeed." ED 37 (October, 1971), 30-31. 
CROSSMAN, DAVID. "A Study of the Use of Language Laboratories in a Sample of Public Schools in New York State." Dissertation Abstracts 29 (1968), 3908A (Syracuse).

DAVID, JEAN. "L'exploitation de textes continus en laboratoire de langues." LanM 62 (1968), 691-700.

DAYAN, F. "Literary Tests in the Language Laboratory: Three Formulas." NTLTL 7,2 (1968), 12-15.

DENHAM, PARICIA. "Remedial Work with Adults in the Language Laboratory." EngLT 23,1 (October, 1968), 39-43.

DEPARTMENT OF EDUCATION and SCIENCE, Education Survey 3: Language Laboratories. London: HMSO, 1968.

DICKINSON, LESLIE. "The Language Laboratory and Advanced Teaching." EngLT (London), 25,1 (October, 1970), 32-42.

DINSON, ESTHER. "The Language Laboratory in Denmark." NALLDJ 6, 1 (October, 1971), 14-21.

DODGE, JAMES W. "National Association of Language Laboratory Directors." AvI 13,6 (June-July, 1968), 562-63.

DODGE, JAMES W. "On Foreign Language Laboratories." NALLDJ 4,2 (December, 1969), 36-38.

DODGE, JAMES W. "On Media in Foreign Language Teaching." in Dimension: Languages '69, Proceedings of the 5th Southern Conference on Language Teaching. Atlanta (February, 1969), 136-40.

DODGE, JAMES $W$. "On Planning a Language Laboratory." in Dimension: Languages '69, Proceedings of the 5th Southern Conference on Language Teaching. Atlanta (February, 1969), 141-46.

DUMONT, JACQUES. "Les Dangers de l'utilisation inconsideree et abusive du laboratoire de langues." NALLDJ 5,1 (October, 1970), 37-55.

DUMONT, JACQUES, "More About Abuse." NALLDJ 5,2 (December, 1970), 46-47.

ENGLE, HENRY T. "What's Happening with Dial Access?" AvI 15,1 (January, 1970), 19-21.

EVANS, LYN. "The Use of the Language Laboratory for Phonetics at Advanced Levels of English Learning." $L L$ 20,1 (June, 1970), 109-25.

FARRINGTON, BRIAN. "The Place of the Language Laboratory in a University French Department." AvLJ 7,1 (Spring, 1969), 19-24.

FORRESTER, DOROTHY L. "The Effectiveness of the Language Laboratory with Particular Reference to Secondary Schools in Britain." University of Essex Language Centre: Occasional Papers 2. Colchester: University of Essex, 1968. 


\section{Bibliography}

FROESE, E. "The Language Lab Work. Some Practical Considerations." RLJ 24,88 (July, 1970), 29-32.

GEORGE, H. V. "Small Language Laboratory Design." English Language Teaching (London) 24,2 (January, 1970), 133-37.

GIONET, ARTHER J. "A Dial-Access System." NALLDJ 4,1 (October, 1969), 72-75.

GLENN, LEONA. "University Labs as a Training Ground for Teachers." National Association of Language Laboratory Directors Journal 4,1 (October, 1969), 15-19.

GOTTSCHALK, MARTIN E. "A Routine for the Open-Hour-Lab." NALLDN 3,2 (December, 1968), 13-15.

GRIFFITHS, B. T. "A Repeater in the Language Laboratory." AvLJ 7,3 (Winter, 1969-70), 173-79.

GROSJEAN, GLEN M. and JESSE O. SAWYER. "Format Preferences in Publishers' Recordings." NALLDJ 4,1 (October, 1969), 68-71. GROTHEN, HAROLD. "The Language Laboratory." Illinois Journal of Education 59,3 (March, 1968), 3-15. ED 022294.

GUTSCHOW, HARALD. "The Present Status of Methodology and Theory of Language Laboratory Use." (In German) Sprachlabor 3 (September, 1969), 80-95.

HAMSON, ERWIN M. "The Closed Booth." AvLJ 6, 2 \& 3 (Winter, 1968-69), 74-77.

HANS, F. H. "Stimulus: Pedagogical Demands; Response: Technical Realization. A Conversation between School and Industry." (In German) Erfahrungsaustausschring Sprachlabor 17 (November, 1970), 1-5.

HANSON, EDWIN M. "The Closed Booth." NALLDN 3,1 (October, 1968), 12-17.

HEDGER, BRIAN. "Some Questions About Language Laboratories." EngLT 23,2 (January, 1969), 132-38.

HIGGINS, J. J. A Guide to Language Laboratory Material Writing. Oslo-Bergen-Troms (1969).

HIGGINS, J. J. and WINDSOR J. LEWIS. "Teaching Intonation in the Language Laboratory." EngLT 24,1 (October, 1969), 46-48.

HILL, L. A. "Language Laboratory." EngLT 22 (January, 1968), 139-42.

HOCKING, ELTON, "A Case Study: The Language Laboratory in a Large Suburban School District." MLJ 52,2 (February, 1968), 84-86.

HOCKING, ELTON. "The Laboratory in Perspective: Teachers, Strategies, Outcomes." MLJ 53,6 (October, 1969), 404-10. 
HOCKING, ELTON. "The Language Laboratory in the USA." in Modern Language Teaching: Papers from the 9th F.I.P.L.V. Congress, Hans Jalling, Ed., London: Oxford U. P., (1968), 47-53.

HOCKING, ELTON. "Technology in Foreign Language Teaching." MLJ 54,2 (February, 1970), 79-91.

HOCKING, ELTON and W. FLINT SMITH. "Language Laboratory Teaching and Learning in the United States." Sprachlabor 1 (March, 1969), 21-29.

HODGSON, S. S. "Language Lab Well Worth the Effort." TES 2826 (July 18, 1969), 35.

HOLDEN, C. M. "The Tanberg Mark III." Modern Languages 51,3 (September, 1970), 96-97.

HORVAY, FRANK D. "Laboratory Work in College German." Die Unterrichtspraxis 1,2 (Fall, 1968), 15-24.

HOUPT, WILLIAM P. "The Pennsylvania Foreign Language Research Project." GQ 42,2 (March, 1969), 308-10.

IRVING, EVELYN, U. "Final Examination in the Language Laboratory." NALLDN 3,3 (March, 1969), 14-16.

"It's Cheaper If It's Mobile," TES 2779 (August 23, 1968), 327.

IZAKOVIC, V. "The Two Basic Uses of the Language Laboratory and the Various Types of Laboratory." ZPSK (Berlin) 22,6 (1969), 596-601.

JALLING, HANS. "Language Laboratories in University Teaching in Sweden." NALLDN 3,4 (May, 1969), 5-15.

JAMES, CARL. "A Rationale for Developing Foreign Language Reading Skills." NALLDJ 4,4 (May, 1970), 15-26.

JARLETT, FRANCIS G. "The Falsely Accused Language Laboratory. Twenty-Five Years of Misuse." NALLDJ 5,4 (May, 1971). 27-43.

JARVIS, GILBERT A. "Systematic Preparation of the Multiple Choice Listening Test." NALLDJ 5,2 (December, 1970), 18-25.

JESCH, JORG. "The Language Laboratory in Native-Language Instruction." (In German) Sprachlabor 4 (December, 1970), 109-17.

JIVEN, L. M. A Study of Language Laboratory Teaching in German. (Didakometry Ser., No. 7) Malmo, Sweden: School of Education, 1966. ED 044059.

JONES, BETTY M. "Language Laboratory Audio Program: High School: Advanced French." NTLTL 7,1 (1967), 54-57, \& 2 (1968), 24-28

KAULFERS, WALTER V. "High School Foreign Language - Developments and Prospects." EdF 34,3 (March, 1970), 383-93. 


\section{Bibliography}

KELLER, GOTTFRIED and LUDWIG HOCHGESCHWENDER. "The Use of the Projector in the Language Laboratory." (In German) Sprachlabor 2 (June, 1970), 45-51.

KIRCH, MAX S. "Visuals in the Language Laboratory." NALLDJ 4,2 (December, 1969), 32-35.

KOBERSKY, EVA. "Language Laboratory Exercises in an English Course for Beginners." Visual Education (London) (December, 1970), 10-11.

KRYNITZ, ROY. "Educational Technology - How, When, Where?" NALLDJ 5,3 (March, 1971), 14-22.

LALLY, DALE V., JR. "Dial Access at Marquette University." NALLDJ 5.1 (October, 1970), 56-63.

LAMERAND, R. Théories d'enseignement programmé et laboratoires de langues. Bruxelles: Labor, 1969.

"LANGUAGE LABORATORIES DON'T BITE." TES 2783 (September 20, 1968), 553.

LANGUAGE LABORATORY TEACHING. Bloomington, Indiana: Indiana Language Program, Indiana University, 1968.

LANGR, BERNARD J. "Using the Pennsylvania Language Laboratory Films." NALLDJ 4,2 (December, 1969), 23-29.

LARSSON, BARBHO. "On Questions of an Effective Drill System in the Language Laboratory in German Instruction for Advanced Students." (In German) DaF 7, 1-2 (1970), 102-11.

LeCOMTE, JEAN and JEAN-MARC GEBLER. "The Language Laboratory." Education and Culture 11 (February, 1969), 23-27.

LEON, MONIQUE. "Réflexions sur le laboratoire de langues et la linguistique appliquée." CMLR 26,2 (January, 1970), 20-26.

LEWIS, W. C. "Buying an Audio Cassette Recorder: Things to Keep in Mind." Educational Product Report 3 (February, 1970), 8-10.

LOTT, B. "Hard Thinking in Software." TES 2788 (October 25, 1968), 915.

LOVEDAY, L. C. '"The Ostle 'Majorlab.' " NL 51,3 (September, 1970), 97-98.

LURJE, A. S. and A. D. REICHSTEIN. "Exercises for Advanced Students in the Language Carrel." (In German) DaF 8,1 (1971), 35-43.

MARTIN, WILLARD. "A Report on a Discussion Conference on the West Chester, Pennsylvania, Study." NALLDJ 4,1 (October, 1969), 64-67. 
MARXHEIMER, E. "Comments on The Pennsylvania Project: Challenge for the Secondary School Laboratory." NALLDN 3,3 (March, 1969), 20-22.

MATHIEU, G. "Pause That Repels, or Technology to the Rescue of Taped Language Exercises." HSJ 51 (May, 1968), 348-52.

MAURER, FRANZ. "The Village Model: A Compact Language Laboratory." (In German) Sprachlabor 1 (March, 1970), 8-15.

McKIM, LESTER W. "Designing and Using Language Laboratories." $A v I$ 13,5 (May, 1968), 454-56.

MEDER, ZOLTEN, "The Language Laboratory and Foreign Language Teacher Training." NALLDJ 4,4 (May, 1970), 10-14.

MEIDEN, WALTER and JOSEPH A. MURPHY. "The Use of the Language Laboratory to Teach the Reading Lesson." MLJ 52,1 (January, 1968), 23-25.

MESSNER, D. M. "Speakirg and Conversaticn Laboratory: A Supplement to Learning Devices." Minresota Journal of Education 43 (May, 1968), 14-15.

MEYER, G. T. "Mathematics without Blackboards; An Innovative Use of the Language Laboratory." MLJ 52,6 (October, 1968), 341-44.

MIKESELL, NORMAN. "Offering and Using Consultant Services." NALLDJ 4,1 (October, 1969), 43-50.

MILDENBERGER, ANDREA S. and ALLEN YUAN-HENG LIAO. "ERIC Documents on the Teaching of Foreign Languages: List Number 1 Language Laboratories." NALLDN 3,2 (December, 1968), 19-24.

MILES, JAMES S. "The Individual Dominated Educational Administration System." NALLDJ 5,2 (December, 1970), 11-17.

"Mobile Language Lab Cuts Costs." TES $2 \cong 09$ (Fcbruary 10, 1971), 38.

MONTAGNE, COL. H. P. "The Wider Uses of the Language Laboratory." NALLDN 3,2 (December, 1968), 16-19.

MONTGOMERY, MICHAEL. "Exploiting the Tape-Recorder." EngLT 25,1 (October, 1970), 19-27.

MORIN, URBAIN. "Comparative Study of Three Types of Language Laboratories in the Learning of a Second Language." CMLR 28,1 (October, 1971), 65-67.

MORRISON, H. W. and E. N. ADAMS. "Pilot Study of a CAI Laboratory in German." MLJ 52,5 (May, 1968), 279-87.

MYERS, THOMAS N. "A Budget Cassette Lab." NALLDJ 5,4 (May, 1971), 47-52. 


\section{Bibliography}

NABER, RICHARD H. "Dial Access Information Retrieval Systems, Circa 1967." Illinois Journal of Education 59 (March, 1968).

NORRISH, NORMA. "Teaching Techniques and Primary School French in the Language Laboratory." BabJA 7,1 (April, 1971), 17-23.

NORSTRAND, HOWARD L. "The Language Laboratory and the Sociological Context." NALLDJ 4,3 (March, 1970), 23-38.

OETTINGER, A. and S. MARKS. "Educational Technology: New Myths and Old Realities." Harvard Ed. Review 38 (Fall, 1968), 697-755.

OLECHOWSKI, RICHARD. "Experiments to Compare the Effectiveness of Various Types of Language Laboratory with Children and Adults." (In German) Sprachlabor (Frankfurt am Main), 4 (December, 1970), 98-103.

OTTO, FRANK. "The Teacher in the Pennsylvania Project." MLJ 53,6 (October, 1969), 411-20.

PHILLIPS, ROBERT. "Using the Tape Recorder to Correct Student Compositions." Hispania 51,1 (March, 1968), 126-27.

PILL, GEOFFREY. "How to Use the Language Lab Without Actually Feeling Guilty." NALLDJ 5,4 (May, 1971), 35-42.

PLASTRE, GUY. "The Language Lab Director." Education Canada 9,3 (September, 1969), 34-36.

PLASTRE, GUY. "Which Language Lab to Do What?" (Expanded text of paper presented at the 15th Conference of AEFO, Ottawa, Ontario, January 20, 1968) ED 041491.

PLEASANTS, JEANNE V. The Language Laboratory and the Teaching of Literature. NTLTL (1968-1972), General Editor, Language Laboratory, Columbia University, New York 27.

POULTER, VIRGIL L. "Computer-Assisted Laboratory Testing." $M L J$ 53,8 (December', 1969), 561.64.

RAGUSA, OLGA. "Effective Utilization of the Language Laboratory." NALLDJ 9,1 (November, 1969), 1-9.

RALLO, JOHN A. "Foreign Language Resource Center - A Step Forward." NALLDJ 4,3 (March, 1970), 14-22.

REES, ALUN L. W. "Running a Language Laboratory." LyC 27 (March, 1968), 1-11. ED 020505.

REID, CONSTANCE. "A Linguistic Coordinator."NALLDN 3,1 (October, 1968), 9-11.

REINERT, HARRY. "Creative Laboratory Usage." NALLDJ 4,1 (October, 1969), 57-63. 
RIDLER, P. J. "Language Laboratories - A Compromise Solution." AvLJ 7,1 (Spring, 1969), 27-28.

RIDLER, P. J. "Language Laboratories or Electronic Classroom?" TES 2878 (July 17, 1970), 37,40.

RIPPE, ADOLF and ANGELA KAMMERER. "Suggestions for Planning and Organizing the Language Laboratory." (In German) Sprachlabor 3 (September, 1970), 65-70.

ROEMMELE, J. A. "Visual Aspect of Sitting Booths in a Language Laboratory." EngLT 22 (January, 1968), 142-47.

ROSS, L. "Improving the Effectiveness of Language Laboratory Work." AvLJ 8,1 (Spring, 1970), 25-35.

ROSWELL, MAY. "Toward Optimum Use of the Language Laboratory." GQ 41,3 (May, 1968), 495.

ROTTGER, GERHARD. "Latin in the Language Laboratory." (In German) Sprachlabor 1 (March, 1970), 15-23.

ROULET, E. “Quelques grammaires utiles à l'élaboration d'exercices structuraux pour le laboratoire de langues." Contact 12 (January, 1969), 12-21.

ROULET, E. "The Training of Teachers in Language Laboratory Techniques and the Choice of Teaching Material for Tapes." I V $T$ Bulletin Pédagogique (Nancy) 2 (1970), 137-44.

ROWE, A. E. "Problem of Acoustics." TES 2837 (October 3, 1969), 43. ROWLINSON, W. "Do We Need To Spend So Much on Language Labs?" TES 2823 (June 27, 1969), 2122.

RUPLIN, F. A. and J. R. RUSSELL. "Towards Structured Foreign Language Study: An Integrated German Course." MLJ 54,3 (March, 1970), 174-83.

RUSSON, LESLIE. "The Creative Use of Language and the Problem of Perfectionism in the Language Laboratory." IV T Bulletin Pédagogique (Nancy) 2 (1970), 47-51.

SAAVEDRA, B. H. "Applied Linguistic Research Center." El Paso Public Schools MLJ 53,2 (February, 1969), 97.

SAGER, J. C. "The Language Laboratory and Contextual Teaching Methods." IRAL 7,3 (August, 1969), 217-29.

SAWYER, JESSE O. "Some Modest Proposals." NALLDJ 5,3 (March, 1971), 9-13.

SCHINDLER, FRANK. "Structures of Communication in the Classroom and the Language Laboratory; Analyses from a Phonetic Aspect." (In German) Sprachlabor 2 (June, 1970), 33-45. 


\section{Bibliography}

SCHNEIDER, BRUNO. "Language Laboratory Exercises for the Senior Classes of the Grammar School (French)." Praxis 15,2 (1968), 169-80.

SCHNEIDER, BRUNO. "On the Introduction of Graphic Elements in Post-Laboratory Instruction." (In German) Sprachlabor 2 (June, 1970), 51-59.

SCHNEIDER, BRUNO. "Sprachlaborübungen für die gymnasiale Oberstufe FranzOzisch." Praxis 15,2 (1968), 169-80.

SCHNEIDER, ALFRED. "Übungen in Sprachlabor und ihre Zweckdienlichkeit im Fremdsprachenunterricht." RPA 9 (1968), 35-40.

SCHRAND, HEINRICH. "The Evaluation of Oral Achievement in the Language Laboratory." (In German) Sprachlabor 1 (March, 1970), 2-8.

SCHWENKER, DOUGLAS and D. CHAMBERS. "Dial Access Retrieval vs. The Tape Lending Library." NALLDJ 4,4 (May, 1970), 66-68.

SISSON, CYRUS R. "The Effect of Delayed Comparison in the Language Laboratory on Phoneme Discrimination and Pronunciation Accuracy." LL 20,1 (June, 1970), 69-88.

SMITH, L. et. al. "Communication Skills through Self-Recording." Today's Education 60 (January, 1971), 18-20.

SMITH, PHILLIP D. "How Effective is the Language Lab?" A Report of the Pennsylvania Research Project. NALLDN 3,1 (October, 1968), 5-8.

SMITH, PHIL D. "Keep Those Language Labs Running!" SMan 13,3 (March, 1969), 47-48.

SMITH, PHILLIP D. and HELMUT A. BARANYI. A Comparison Study of the Effectiveness of the Traditional and Audiolingual Approaches to Foreign Language Instruction Utilizing Laboratory Equipment. Final Report, Project No. 7-0133; OEC-1-7-0701330445. Washington, D. C.: U. S. Department of Health, and Welfare, 1968.

SMITH, PHILLIP D., JR. and EMANUEL BERGER. An Assessment of Three Foreign Language Teaching Strategies Utilizing Three Language Laboratory Systems. Final Report. Project No. 5-0683; OE-7-48-9013-272. Washington, D. C.: U. S. Department of Health, Education, and Welfare, 1968. ED 021512.

SMITH, P. D., E. M. BIRKMAIER, and D. L. LANGE. "Static in the Language Lab." Today's Education 58 (October, 1969), 49-51.

SMITH, R. W. "Closed Circuit Television in the Language Laboratory." TES 2,801 (January 24, 1969), 253. 
SMITH, W. F. The Language Laboratcry and the Electronic Classroom: A Comparison of the Relative Contribution to Achievement in Three Languages in the Comprehensive High School. Lafayette, Indiana: Purdue University, 1969 (Unpublished Doctoral Dissertation).

SMITH, W. F. "Language Learning Laboratory." in Britannica Review of Foreign Language Education, Vol. 2, edited by Dale L. Lange. Chicago; Encyclopedia Britannica Inc. (1970), 191-237.

SMITH, W. F. and ELTON HOCKING. "The Fallacy of Accessibility." NALLDN 3,3 (March, 1969), 10-13.

SMITH, W. F. and ELTON HOCKING. "The Student's Attitude: Revisited." NALLDJ 4,1 (October, 1969), 51-56.

SMITH, W. F. and LAEL LITTLEFIELD. The Electronic Classroom, the Broadcast and the Record-Playback Language Laboratory: Their Contribution to Achievement in Beginning Language Learning. Bloomington: ILP, Indiana University, 1969. ED 040623.

SMITHER, WILLIAM J. "Language Laboratory Administration and Maintenance." Dimension: Languages '69, Proceedings of the Fifth Southern Conference on Language Teaching. Atlanta (February, 1969), 147-50.

SMITHER, WILLIAM J. "Recorded Speaking Tests in the Language Laboratory." Dimension: Languages '69 Proceedings of the Fifth Southern Conference on Language Teaching. Atlanta (February, 1969), 151-57.

SPEARS, RICHARD A. "A Second Look at Retrieval Systems." NALLDJ 4,4 (May, 1970), 72-80.

STANKOVA, E. "Practical English Phonetics in the Language Laboratory." EngLT 24 (May, 1970), 250-54.

STERN, H. H. "Some British Writings on the Use of the Language Laboratory." (Compiled by the author November, 1968), NALLDN 3,2 (December, 1968), 25.26.

SWALES, J. "Language Laboratory Materials and Service Courses: Problems of Tape Course Design for Science Students." AvLJ 8,1 (Spring, 1970), 37-41.

TAILLON, LÉOPOLD. "Fiche de contrôle pour laboratoire: moyen d'assurer le succès de l'apprentissage programmé." AvLJ 5,3 (Spring, 1968), 133-35.

THEUMA, JEAN R. "A Rationale for Improving Student Recorder Controls in Language Laboratories of the Level III Type." NALLDN 3,1 (October, 1968), 18-20. 


\section{Bibliography}

THEUMA, JEAN R. "Which Switch is Which? A Better Design for Student-Operated Tape Recorders." AvI 13,7 (September, 1968), 726-27.

THEUMA, JEAN V. Your Language Laboratory Facilities: Present and Future. Honolulu: University of Hawaii (1968), ED 026916.

THIMANN, I. C. "Waste of Money and a Personal Nightmare?" TES 2843 (November 14, 1969), 58.

TIGGEMANN, WERNER. "Traditional Methods and Language Laboratory Work." (In German) Praxis 17,1 (January, 1970), 41-51.

TOBIN, C. J. "Apologia pro Laboratorio." TES 2788 (October 25, 1968), 904.

TORKELSON, G. M. and J. P. DRISCOLL. "Utilization and Management of Learning Resources." Review of Educational Research 38 (1968), 129-59.

TURNER, E. DAYMOND, JR. Correlation of Language Class and Language Laboratory. ERIC Focus Report on the Teaching of Foreign Languages. New York: MLA/ACTFL Materials Center, 1969.

TURNER, JOHN D., ed. Programming for the Language Laboratory. London: University of London Press, 1968.

TURNER, JOHN D., ed. Using the Language Laboratory. London: University of London Press, 1968.

VALETTE, REBECCA M. "The Pennsylvania Project, Its Conclusions and Its Implications." MLJ 53,6 (October, 1969), 396-404.

VALETTE, REBECCA M. "Some Conclusions to be Drawn from the Pennsylvania Study." NALLDN 3,3 (March, 1969), 17-19.

VALETTE, REBECCA M. "The Use of the Language Laboratory in Intermediate and Advanced Classes." NALLDN 2,3 (May, 1968), 4-9.

VAN ABBE, DEREK. "Differences Between Audio-Active and AudioActive-Comparative Language Laboratories." AvLJ 6,1 (Summer, 1968), 22-24.

WAKEMAN, ALAN. "Are Language Laboratories Worth the Money?" Visual Education (London), (January, 1971), 19-21.

WERTHEIMER, L. "Language Studies in Public Libraries." $A L A$ Bulletin 62 (September, 1968), 985-92.

WEXLER, P. J. "Assumptions of the Standard-Format Lab Exercise." University of Essex Language Centre: Occasional Papers 2, Colchester: 1968.

WHARTON, A. "More Classroom Conversation." EngLT 24,1 (October, 1969), 27-29. 
WIDMANN, ANNEMARIE. "Language Laboratory Courses from the Students Point of View: Results of Two Enquiries. (In German) PLUU (Berlin), 7,4 (1970), 222-36.

WODOWSKI, ETTY. "Une éxperience: le labortoire de langues à l'université de Tel-Aviv." Le Français dans le Monde 64 (April/ May, 1969), 33-37.

WOODS, H. A. "Problems of the Foreign Language Laboratory Director." AvI 13 (May, 1968), 457-59.

YALDEN, JANICE. "Listening Comprehension in the Language Laboratory." NALLDJ 5,4 (May, 1971), 11-26.

ZEITNER, PETER O. "Don't Waste Your Time Cleaning Recording Heads!" AvI 13,1 (January, 1968), 64-65.

\begin{tabular}{|c|c|}
\hline $\mathrm{AE}$ & Adult Education \\
\hline AvCR & Audio-Visual Communication Review \\
\hline AvI & Audiovisual Instruction \\
\hline AvLJ & Audiovisual Language Journal \\
\hline BabJA & $\begin{array}{l}\text { Babel. Journal of the Australian Federation of Modern } \\
\text { Language Teachers Association }\end{array}$ \\
\hline CMLR & Canadian Modern Language Review \\
\hline Contact & Contact: FIPLV \\
\hline DaF & Deutsch als Fremdsprache \\
\hline ED & Education Digest \\
\hline EdF & The Educational Forum \\
\hline EngLT & English Language Teaching \\
\hline FLA & Foreign Language Annals \\
\hline FMonde & Le Francais dans le Monde \\
\hline FR & The French Review \\
\hline GQ & German Quarterly \\
\hline HSJ & High School Journal \\
\hline IRAL & $\begin{array}{l}\text { International Review of Applied Linguistics in Language } \\
\text { Teaching }\end{array}$ \\
\hline JESL & Journal of English as a Second Language \\
\hline LanM & Les Langues Modernes \\
\hline LL & Language Learning \\
\hline LyC & Lenguaje y Ciencias \\
\hline ML & Modern Languages \\
\hline MLJ & Modern Language Journal \\
\hline NALLDJ & $\begin{array}{l}\text { National Association of Language Laboratory Directors } \\
\text { Journal }\end{array}$ \\
\hline NALDN & $\begin{array}{l}\text { National Association of Language Laboratory Directors } \\
\text { Newsletter }\end{array}$ \\
\hline
\end{tabular}

\section{TABLE OF ABBREVIATIONS}




\section{Bibliography}

NTLTL Newsletter for Teaching Language Through Literature

PLUU Programmiertes Lernen Unterrichtstechnologie und Unterrichtsforschung

Praxis Praxis des Neusprachlichen Unterrichts

RLJ Russian Language Journal

RPA Revue de Phonetique Appliquee

SMan School Management

SprachlaborDas Sprachlabor und der Audiovisuelle Unterricht

TES Times (London) Education Supplement

TESOLQ TESOL Quarterly

UP Die Unterrichtspraxis

ZPSK Zeitschrift fur Phonetik, Sprachwissenschaft und Kommunikationsforschung 